Suvremena psihologija 20 (2017), 1, 39-51

Izvorni znanstveni rad - UDK 159.913

DOI: $10.21465 / 2017-S P-201-03$

\title{
COMMUNICATION AND SOCIAL SKILLS IN EDUCATION OF HEALTH OCCUPATION STUDENTS*
}

\author{
Mira Klarin \\ University of Zadar, Department for Health Studies \\ Splitska 1, 23000 Zadar \\ mklarin@unizd.hr \\ Vesna Antičević \\ University of Split, University Department for Health Studies \\ Ruđera Boškovića 35, 21000 Split \\ vesna.anticevic@ozs.unist.hr \\ Goran Kardum \\ University of Split, Faculty of Humanities and Social Sciences \\ Chair of psychology \\ Sinjska 2, 21000 Split \\ gkardum@ffst.hr \\ Ana Proroković \\ University of Zadar, Faculty of Humanities and Social Sciences \\ Department of psychology \\ Ulica Mihovila Pavlinovića 1, 23000 Zadar \\ aprorok@unizd.hr \\ Joško Sindik† \\ Institute for Anthropological Research \\ Ljudevita Gaja 32, 10000 Zagreb \\ jsindik@inantro.hr
}

\begin{abstract}
The aim was to investigate whether social skills' training (SST) influences attitudes towards communication skills learning and to validate the Communication Skills Attitudes Scale (CSAS) among students of health studies in the Republic of Croatia. SST (10 workshops) was implemented for this purpose. Seventy 1st year students in four Croatian university health studies were randomly selected to take part in the
\end{abstract}

* This research was supported in part by a grant from the EU Structural Fund (No: HR.3.1.15-0051). 
training and 169 students were part of the control group. CSAS was administered at the beginning and end of training to both groups. The results indicated good metric characteristics in relation to CSAS and its two-factor structure (positive attitude scale and negative attitude scale). Furthermore, we did not record significant changes in attitudes towards communication skills learning in both groups. However, pursuant to average results from the subscales attitudes towards communication skills learning, we noticed that negative attitudes tend to decrease and positive tend to increase. This indicates that 10 workshops might have been insufficient in order to change attitudes.

Key words: validation, communication and social skills, training

\section{INTRODUCTION}

Social skills are significant for all aspects of human life. Klein, DeRouin \& Salas (2006) define social skills as goal-directed behaviours, including communication and competences which are necessary to create interpersonal relations, basic interaction, communication skills, teamwork and conflict resolution. From the above mentioned, it can be clearly noticed that communication skills are a very important part of social skills and they are a condition for the development of social skills. Along with professionalism in the sense of knowledge and skills, both social and communication skills are significant components of health care. Professional conversation between the health care employee and the patient involves communicating the diagnosis, proposing therapy and establishing a trust relationship. Whether the health care professional is to be successful in such activities largely depends on his social and communication skills (Duffy, Gordon, Whelan, Cole-Kelly \& Frankel, 2004). The relationship between the health care professional and patient presents an important component of successful treatment. Social skills can be learnt. However, if there is no continuous training, they can also be forgotten (Aspegren, 1999). Social Skills Training (SST) is a method of achieving social skills development. The basic SST idea comes from a social-cognitive model (SCT) on the mutual influence of cognitive and environmental factors on social behaviour. SCT posits that individuals make decisions based on internal factors such as emotions, expectations, attitudes and knowledge, as well as environmental factors such as influence on others, social norms and physical environment, which is in turn influenced by behaviour (Bandura, 1986). Methods that are used in SST are more effective for improving cognitive and skill-based outcomes than other methods like lectures and observation (Bandura, 1977). Therefore, numerous study programs in health care professions include some form of social skills learning in their curriculum. Numerous research indicates the positive effect of Communication/Social Skills Training on health care professionals and the need for the development of these skills, especially in doctors and nurses (Sargeant, MacLeod \& Murray, 2011; Kourkouta and Papathanasiou, 2014; Ha \& Longnecker, 2010; Barth \& Lannen, 2010; Khodadadi, Ebrahimi, Moghaddasian, \& Babapour, 2013; Seo, Ahn, Byun \& Kim, 2007). 
The positive effect of Social Skills Training was confirmed by findings of meta analytical studies which were conducted on populations of children and young people (Hanson, Nangle \& Meyer, 1998) and adults (Klein et al., 2006). Teaching students social skills during their study is an initiative that contributes to gaining social skills competence (Duffy et al., 2004). By summarizing the findings of numerous different studies which investigated SST effects, Aspegren (1999) concludes that all studies which were performed by students of nursing and dentistry and among young and older doctors confirm training efficiency. The exception is one study which does not support the conclusion. The reason for this is a short training period (three hour introductory lecture accompanied by 10 hours of clinical practice). It is interesting to point out that students with a low level of social skills before training benefit the most from training (Aspegren, 1999). Most studies indicated that students' social skills decrease over the course of the study and only a small number of studies indicated that they increase. Aspergen (1999) argued that this is due to a different social skills evaluation method which, in this case, was the evaluation of patients. As it has already been mentioned, a precondition for the development of social skills is the development of communication skills and in this sense, attitudes towards communication skills training during the study need to be taken into consideration. If these attitudes are negative, it can be assumed that the SST outcome is going to be small or non-existent. Therefore, one of the SSTs aims is to investigate attitudes towards learning communication skills by informing the students about the importance of communication skills in the health care area and their connection to social skills in general. This paper focuses on SST effect on the students' attitude towards communication skills learning. One of the methods to evaluate the SST effect is to measure the attitudes of training participants or to observe whether training contributes to a change in attitude towards communication skills learning. One of the scales commonly used is the Communication Skills Attitudes Scale (CSAS, Rees, Sheard \& Davies, 2002). By using CSAS, Rees \& Sheard (2002) emphasize that the scale is a reliable instrument for measurement of attitudes towards communication skills learning. Cleland, Foster \& Moffat (2005) also confirmed a high reliability level for both factors obtained through the Communication Skills Scale with students of different years of study. However, the first year students have more positive attitudes towards communication skills learning compared to students of higher years of study. The situation is similar with negative attitudes which are significantly lower with students of lower years.

Relatively numerous researches using CSAS in order to evaluate social skills training can be found in the literature. Rosenthal \& Ogden (1998) state that five years of SST results in a change of students' attitude. On the other hand, one year long training (lasting 30 hours) was proved to be insufficient for the change of attitudes towards social skills learning (Harlak, Dereboy \& Gemalmaz, 2008a). In order to realize the aim of this research, it was necessary to validate Communication Skills 
Attitudes Scale by including the representative number of health study students in the Republic of Croatia.

Specifically, the aim of this research was to check the factor structure and CSAS reliability at the national level and to check the attitude towards communication skills learning as a result of social skills workshops.

\section{METHOD}

Participants

This research used a $2 \times 2$ experimental design with experimental and control groups. In the experimental group, social skills training was used as an independent variable and the training effects were measured in the first and repeated measurement for both groups. 239 students (70 in the experimental and 169 in the control group) from four Croatian health studies were tested in total. There were $83.84 \%$ women and $16.15 \%$ men. Students from the experimental group were selected from the total sample with the help of random number table and they participated in the previously designed 10-days Social Skills Training. The training consisted of 10 workshops whose content was focused on practicing social skills which are relevant to nursing and other health professions. Each topic was dealt with in a 90 minutes' workshop with a group of 10 students. The workshops had the following titles: Introduction to the SST, Communication skills as a part of social skills, Assessment of patients' psychopathological states, Assessment of emotional states and dealing with patient's emotional states, Conversational skills with a patient suffering from acute and chronic health problems, Conversational skills with a patient suffering from acute and chronic psychological disabilities, Empathy and emotional intelligence, Counselling skills in health care, Skills of therapeutic use of silence and pause, and Management skills and conflict resolution skills in health care. Each of the workshops had a standardized structure, according to the following scheme: a review of homework, theoretical introduction to the workshop, role-playing, watching videos, discussions, training, assigning next homework, feedback on the workshop. Workshop trainers were different teachers who taught a Communication Skills Course.

Communication Skills Attitudes Scale (CSAS) was applied among students from both groups at two time points: immediately prior to the beginning of SST and immediately after the SST ended.

\section{Materials}

Attitudes of health studies students were measured with the Communication Skills Attitude Scale (CSAS) (Rees et al., 2002). The original scale was primar- 
ily intended to measure the attitudes of medical students towards communication skills learning. It is a tool that has been most widely used and validated (Anvik et al., 2008). The CSAS was translated into Croatian by three independent researchers using the back-translation method. The CSAS contains 26 statements concerning attitudes towards learning communication skills. Thirteen statements are positively worded and thirteen negatively. Each statement is followed by five boxes in a Likert-like consecutive order, from "Strongly disagree" to "Strongly agree". Both scales range from 13 to 65 with higher scores indicating stronger positive or negative attitudes.

The research was approved by the Ethical Committee of the Health Studies University Department in Split.

\section{RESULTS}

Validation of instruments for testing the attitudes towards communication skills was foreseen within the research scope. Therefore, principal factor analysis was made for this purpose. The results of CSAS scale factorization indicate a clear twofactor structure. The following multiple criteria were used for the extraction: Guttman- Kaiser criterion, Scree test and Parallel analysis. All three criteria support twofactor structure (PAS - Positive Attitude Scale, NAS - Negative Attitude Scale).

By applying Parallel analysis - Random Data Eigenvalues, among others, the first two radicals with average values of 0.818 and 0.704 and with the total percentage of 0.94 and 0.81 were obtained. Original eigenvalues exceed 1. For the first radical, it is 8.33 and for the second it is 1.75 . Table 1. presents matching index after

Table 1. Confirmatory factor analysis with correlation factor

\begin{tabular}{lc}
\hline & Fit indices \\
\hline Discrepancy Function & 0.88 \\
Maximum Residual Cosine & 0.00 \\
Maximum Absolute Gradient & 0.00 \\
ICSF Criterion & 0.00 \\
ICS Criterion & 0.00 \\
ML Chi-Square & 178.58 \\
Degrees of Freedom & 120 \\
p-value & 0.00 \\
RMS Standardized Residual & 0.04 \\
\hline
\end{tabular}


SUVREMENA PSIHOLOGIJA 20 (2017), 1, 39-51

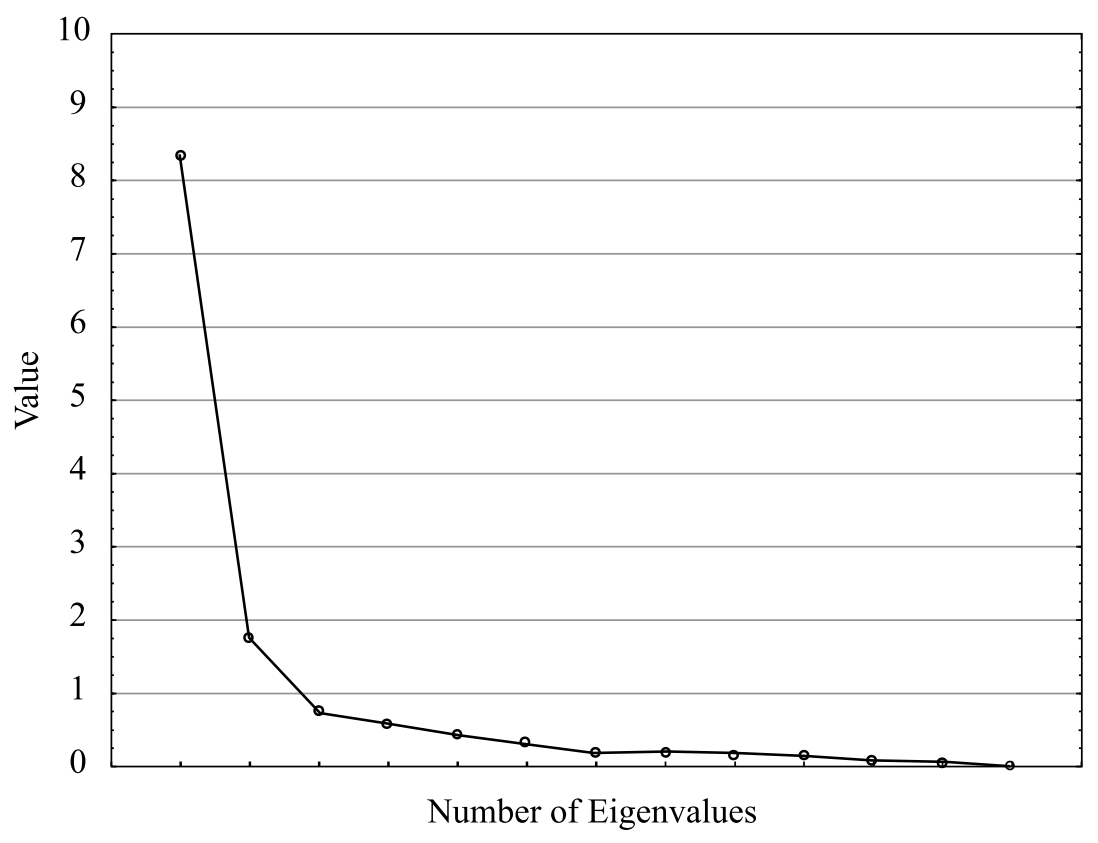

Graph 1. Scree plot of eigenvalues (principal factors analysis)

the implementation of confirmatory factor analysis with correlation factors which indicate well-adjusted two-factor model (PAS and NAS). Scree plot of eigenvalues is shown in Graph 1.

The division of the results at PAS scale is negatively asymmetric while NAS scale results do not significantly deviate from a normal division. Reliability of both scales is satisfactory and for PAS it is Cronbach's alpha $=0.92$ and for NAS Cronbach's alpha $=0.76$.

The second goal of the research was to determine the attitudes towards communication skills in the experimental and control groups of participants, before and after social skills training (Table 2). Therefore, the differences in attitudes towards communication skills between the experimental and control groups were determined at two different points in time: at the starting point (before social skills training) and then after the termination of the social skills training process.

An insight into Table 2 reveals that the means in Positive Attitude Scores (PAS) are higher in the experimental group, both in periods before and after social skills training. On the other hand, the means in Negative Attitude Scores (NAS) are higher in the control group, both in periods before and after social skills training. 
Table 2. Descriptive statistics of positive attitude scores (PAS) and negative attitude scores (NAS) in experimental and control group, before and after social skills training

\begin{tabular}{|c|c|c|c|c|c|c|}
\hline & $\begin{array}{c}\text { Measurement point } \\
(N)\end{array}$ & $M$ & $S D$ & $\begin{array}{l}\text { Measurement point } \\
(N)\end{array}$ & $M$ & $S D$ \\
\hline \multirow[t]{2}{*}{ Experimental (E) } & PAS before $(n=59)$ & 57.05 & 1.01 & NAS before $(n=61)$ & 24.36 & 0.67 \\
\hline & PAS after $(n=59)$ & 57.47 & 0.91 & NAS after $(n=61)$ & 24.08 & 0.78 \\
\hline \multirow[t]{2}{*}{ Control (C) } & PAS before $(n=131)$ & 49.60 & 0.67 & NAS before $(n=133)$ & 28.95 & 0.45 \\
\hline & PAS after $(n=131)$ & 51.49 & 0.61 & NAS after $(n=133)$ & 29.22 & 0.53 \\
\hline
\end{tabular}

Table 3. Two-way Analysis of Variance with Effect Sizes and Powers in Positive Attitude Scores (PAS) and Negative Attitude Scores (NAS) between experimental and control group, before and after social skills training

\begin{tabular}{lcccc}
\hline & $F$ & $p$ & $\eta$ & $\begin{array}{c}\text { Observed power } \\
\text { (alpha =0,05) }\end{array}$ \\
\hline $\begin{array}{l}\text { Positive Attitude Scores (PAS) } \\
\text { Group (E/C) }\end{array}$ & 64.41 & 0.00 & 0.26 & 1.00 \\
Before/After & 2.09 & 0.15 & 0.01 & 0.30 \\
Interaction & 0.84 & 0.36 & 0.00 & 0.15 \\
Negative Attitude Scores (NAS) & & & & \\
Group (E/C) & 50.35 & 0.00 & 0.21 & 1.00 \\
Before/After & 0.00 & 0.99 & 0.00 & 0.05 \\
Interaction & 0.25 & 0.62 & 0.00 & 0.08 \\
\hline
\end{tabular}

Table 4. Bonferroni test with probabilities for Post Hoc Tests error in Positive Attitude Scores (PAS) and Negative Attitude Scores (NAS) between experimental and control group, before and after social skills training

\begin{tabular}{lllll}
\hline & \multicolumn{1}{c}{ Measurement } & (1) & (2) & (3) \\
\hline $\begin{array}{l}\text { Positive Attitude Scores (PAS) } \\
\text { Experimental }\end{array}$ & (1) PAS before & & & \\
& (2) PAS after & 1.00 & & \\
Control & (3) PAS before & 0.00 & 0.00 & \\
& (4) PAS after & 0.00 & 0.00 & 0.21 \\
Negative Attitude Scores (NAS) & & & & \\
Experimental & & & & \\
& (1) NAS before & 1.00 & & \\
Control & (2) NAS after & 0.00 & 0.00 & \\
& (3) NAS before & 0.00 & 0.00 & 1.00
\end{tabular}


The results from Table 3 show that there was no statistically significant difference neither in PAS nor NAS before and after social skills training. The results of post-hoc analysis (Bonferroni test) reveal that social skills training does not significantly affect either the experimental or the control group in relation to PAS and NAS (Table 4). Interaction effects were not significant either for PAS or NAS.

However, there is a significant difference in PAS between the experimental and control group of subjects before the start of training (with relatively large effect size) (Table 4). Namely, in the experimental group, before and after training, statistically significant higher positive attitudes towards learning social skills are found, as compared to the control group (Table 2, Table 4). Similar results are found in NAS as well. A statistically significant difference in NAS is found between the experimental and control group of subjects before the start of training and after training was completed (Table 4). In the control group, before and after the process of training, statistically significant higher negative attitudes towards social skills learning are found, as compared to the experimental group (Table 2, Table 4).

\section{DISCUSSION}

One of the aims of this research was to check the factor structure and CSAS reliability at the national level and the other was to check the attitude towards communication skills learning as a result of social skills workshops. Confirmatory factor analysis confirmed a two-factor original structure of the scale as positive (PAS) and negative (NAS) subscales. Similar results were obtained through translation and application in other countries (Harlak et al., 2008a; Molinuevo, \& Torrubia, 2011). The indicated results go in favour of the factor structure which was proposed by the author and satisfactory reliability of the measurement instrument which makes the Communication Skills Attitude Scale (CSAS) suitable for application among students and health professionals. PAS scale results indicate that the students have a more positive attitude towards communication skills learning while NAS scale results are normally distributed.

After having checked metric characteristics of the measurement instrument, we were interested in seeing how social skills training influenced students' attitudes towards communication skills learning. The results of the implemented research do not support our initial assumption regarding the positive effect of social skills training on the attitudes towards the importance of communication skills learning among health professionals. The differences in positive and negative attitudes between students who took part in training and students who did not take part in training were not recorded. There are several possible explanations. One logical explanation refers to a general difficult change in attitudes. Attitudes are generally very difficult to change once they are formed. It seems justified to conclude that 10 implemented workshops are not enough to change the attitude towards the importance of social 
skills learning. The same results are obtained by Harlak, Gemalmaz, Gurel, Dereboy \& Ertekin (2008b) who concluded that training is not efficient enough to change the students' attitude towards communication skills learning.

By observing the students' attitudes towards the importance of communication skills learning in general, we found that the students have a positive attitude and think that social skills learning is necessary. This trend is greater with the group of students who were involved in the training (experimental group), both before and after the training. By observing average values in the experimental group, we noticed a positive trend in relation to the evaluation of training importance for health care professionals. However, this trend was not statistically confirmed. The group of students who did not take part in training showed more negative attitudes towards social skills learning at the first and second measurement point. Average values indicate that the attitudes become more negative over the course of time. However, this was not statistically significant. In summary, a trend of positive evaluation of social skills learning importance was noticed in both groups. However, the differences between the results which were obtained in the 1st and 2nd measurement point were not statistically significant. In the group of students who took part in the training, there is a tendency to decrease negative attitudes while in the group of students who did not take part in the training, this trend is opposite and there is a tendency to increase negative attitudes. However, this difference was not statistically proved. The obtained results indicate the tendency to increase positive and decrease negative attitudes towards social skills learning. Nevertheless, the fact is that this tendency was not statistically proven. Therefore, it can be concluded that 10 workshops were not enough to change attitudes. On the other hand, the data obtained from literature refers to the effect that training has on the knowledge of empathy (Winefield \& Chur-Hansen, 2000) and to a 5-years long training which results in a change of attitudes (Rosenthal \& Ogden, 1998), while one-year long training (30 hours) does not result in a change of attitudes (Harlak et al., 2008b). In addition, Harlak et al (2008b) emphasize the possibility of obtaining opposite training effect or more negative attitude towards social skills learning importance. This phenomenon is explained by the "boomerang effect" or negative perception of the source of influence (for example, the trainer or the instructor). Considering that the students in both groups study at the same year, it is possible that the control group was not involved in training caused the subjects' resistance.

Furthermore, it needs to be emphasized that the positive attitudes in students who participated in training are almost maximal and negative attitudes are minimal. Similar results were also obtained by other authors who emphasize that the students of the first year of health studies have more positive attitude towards social skills compared to older students (Cleland et al., 2005). This leads us to the conclusion that the students enrolling in health studies, in general, think that social skills learning is important in order to provide health services. This situation is opposite to the one which can be found in students of higher years when the importance of social 
skills in health care decreases (Aspegren, 1999). It is possible that more time in clinical practice leads to a change in attitudes towards social skills. In other words, it results in the clinical context being perceived as a social skills learning context (Sanson-Fisher \& Cockburn, 1997; Ramani \& Leinster, 2008). By observing group differences before and after training implementation, we can see some illogicality. Despite the fact that the groups were randomly formed, the difference in attitudes between the two groups was recorded at the first measurement point. This difference was also present at the second measurement point. These differences indicate more positive and less negative attitudes towards social skills learning in the group of students who took part in training. Motivation factor can be one of the possible reasons for such result. Dividing students in two groups could influence the fact that the students who took part in training have a more positive attitude towards the importance of social skills than the students who did not take part in training. This trend was also recorded in the second measurement after training was implemented. It is important to emphasize that a trend of more negative attitudes was recorded during the second measurement with the students who did not take part in training in relation to the first measurement point. This can be explained in the same manner, namely by a motivational effect. During training, it was noticed that the students who did not take part in training show one type of resistance - protest which could have been manifested in a more negative attitude towards social skills learning. As it can be found in the literature (Rees \& Sheard, 2002) the education level could have influenced the difference in attitudes between the two groups of students at the beginning of the training. The criteria for the selection of students was random numbers criteria. Considering that this research did not take prior knowledge criteria (secondary school criteria) into consideration, there is a question whether the difference in attitudes is the result of different secondary school education (firstyear students of health studies have different secondary school background such as gymnasium, medical school etc.). It is well known that the students who graduated from medical school had much more practice and patient experience as opposed to students who graduated from a gymnasium. Apart from this, unlike lecture based classes, practical classes have a more positive effect on social skills learning (Rutter \& Maguire, 1976., Aspegren, 1999). Future similar researches should take these criteria in consideration.

We were interested in the relation between positive and negative attitudes towards social skills learning. The fact is that these two attitude aspects are negatively related and this was expected. However, this connection with the group of students who took part in training is even greater in the second measurement. The same trend was noticed with students who did not take part in training. In other words, students who evaluate the importance of social skills learning do not have a negative attitude towards learning. Over the course of time, these correlations are increased in both students' groups. After training, both positive and negative attitudes tend to present poles of the same dimension (attitudes in general) and not separate factors. 
This tendency can be attributed to the effect of other courses within health studies (for example, communication skills course) which were taken by both groups of students in the common study program.

One important limitation of this research refers to a methodological error which was made while forming the experimental and control groups of students. Education level and gender present variables which, very likely, caused the difference in attitudes towards social skills learning at the beginning of training. Also, the fact that training was carried out by different teachers could have affected the results. This fact definitely needs to be considered in future researches.

The greatest contribution of this research is that the students from all university health studies in the Republic of Croatia (apart from Rijeka) took part. Therefore, we can state that the measurement instrument validation was performed at the national level. Furthermore, confirmed factor structure and satisfactory reliability make this measurement instrument suitable for the measurement of attitudes towards communication skills learning in students of different health studies. Another contribution is a proposal of "Social Skills Training" course as an elective course at higher years of university health studies (2nd year of undergraduate and 2nd year of graduate health study). This shall definitely contribute to health study program quality.

\section{REFERENCES}

Anvik, T., Grimstad, H., Baerheim, A., Fasmer, O.B., Gude, T., Hjortdahl, P., Vaglum, P. (2008). Medical students' cognitive and affective attitudes towards learning and using communication skills - a nationwide cross-sectional study. Medical Teacher, 30(3).

Aspegren K. (1999). Teaching and learning communication skills in medicine: a review with quality grading of articles. Medical Teacher, 21, 563-570.

Bandura, A. (1986). Social foundations of thought and action: A social cognitive theory. US: Prentice-Hall, Inc.

Bandura, A. (1977). Social learning theory. Englewood Cliffs, NJ: Prentice Hall.

Barth, J., \& Lannen, P. (2010). Efficacy of communication skills training courses in oncology: a systematic review and meta-analysis. Annals of Oncology, 22(5), 1030-1040.

Cleland, J., Foster, D. \& Moffat, M. (2005). Undergraduate students' attitudes to communication skills learning differ depending on year of study and gender. Medical Teacher, 27(3), 246-251.

Duffy, F.D., Gordon, G.H., Whelan, G., Cole-Kelly, K. \& Frankel, R. (2004). Assessing Competence in Communication and Interpersonal Skills: The Kalamazoo II Report. Academic Medicine, 79(6), 495-507.

Ha, J.F., \& Longnecker, N. (2010). Doctor-Patient Communication: A Review. The Ochsner Journal, 10(1), 38-43.

Hanson, D. J., Nangle, D. W., \& Meyer, K. A. (1998). Enhancing the effectiveness of social skills interventions with adolescents. Education and Treatment of Children, 21(4), 489-513. 
Harlak, H., Dereboy, C. \& Gemalmaz, A. (2008a). Validation of a Turkish translation of the Communication Skills Attitude Scale with Turkish medical students. Education for Health, 21(1), 55.

Harlak, H., Gemalmaz, A., Gurel, FS., Dereboy, C. \& Ertekin, K. (2008b). Communication Skills Staining: Effects on Attitudes toward Communication Skills and Empathic Tendency. Education for Health, 21(1), 21-62.

Khodadadi, E., Ebrahimi, H., Moghaddasian, S, \& Babapour, J. (2013). The Effect of Communication Skills Training on Quality of Care, Self-efficacy, Job Satisfaction and Communication Skills Rate of Nurses in Hospitals of Tabriz, Iran. Journal of Caring Sciences, 26(1), 27-37.

Klein, C., DeRouin, R. E. \& Salas, E. (2006). Uncovering Workplace Interpersonal Skills: A Review, Framework, and Research Agenda. In G. P. Hodgkinson and J. K. Ford, (eds.), International Review of Industrial and Organizational Psychology (pp. 80-126). Chichester: John Wiley \& Sons.

Kourkouta, L., \& Papathanasiou, I. (2014). Communication in Nursing Practice. Mater Sociomed, 26(1), 65.

Molinuevo, B. \& Torrubia, R. (2011) Validation of the Catalan version of the communication skills attitude scale (CSAS) in a cohort of South European medical and nursing students. Education for Health, 24(1), 499.

Ramani, S. \& Leinster, S. (2008). AMEE Guide no. 34: Teaching in the clinical environment. Medical Teacher, 30, 347-364.

Rees, C. E. \& Sheard, C. E. (2002). The relationship between medical students' attitudes towards communication skills learning and their demographic and education-related characteristics. Medical Education, 36, 1017-1027.

Rees, C.E., Sheard, C.E. \& Davies, S. (2002). The development of a scale to measure medical students' attitudes towards communication skills learning: the Communication Skills Attitudes Scale (CSAS). Medical Education, 36, 141-147.

Rosenthal, J. \& Ogden, J. (1998). Changes in Medical Education: the beliefs of medical students. Medical Education, 32, 127-132.

Rutter DR, Maguire P. (1976). History-taking for medical students. II. Evaluation of a training programme. Lancet. 2, 558-560.

Sanson-Fisher, R \& Cockburn, J. (1997). Effective teaching of communication skills for medical practice selecting an appropriate clinical context. Medical Education, 31, 52-57.

Sargeant, J., MacLeod, T., \& Murray, A. (2011). An interprofessional approach to teaching communication skills. Journal of Continuing Education in the Health Professions, 31(4), 265-267.

Seo, J., Ahn, S., Byun, E., \& Kim, C. (2007). Social Skills Training as Nursing Intervention to Improve the Social Skills and Self-Esteem of Inpatients with Chronic Schizophrenia. Archives of Psychiatric Nursing, 21(6), 317-326.

Winefield, H.R. \& Chur-Hansen, A. (2000). Evaluating the outcome of communication skill teaching for entry-level medical students: does knowledge of empathy increase? Medical Education, 34(2), 90-94. 


\title{
KOMUNIKACIJSKE I SOCIJALNE VJEŠTINE U OBRAZOVANJU STUDENATA ZDRAVSTVENIH STUDIJA
}

\begin{abstract}
Sažetak
Cilj ovog istraživanja bio je utvrditi učinak Treninga socijalnih vještina (TSS) na stavove studenata o korisnosti učenja komunikacijskih vještina na zdravstvenim studijima. Sljedeći cilj je bio validirati Skalu stavova o učenju komunikacijskih vještina (SSKV) na hrvatskom jeziku. Za postizanje istraživačkih ciljeva proveden je Trening socijalnih vještina (10 radionica). Sadržaj TSS bio je fokusiran na uvježbavanje relevantnih socijalnih vještina. Sedamdeset studenata 1. godine sa zdravstvenih studija četiriju hrvatskih sveučilišta je slučajno odabrano za sudjelovanje u treningu (eksperimentalna skupina), a preostalih 169 studenata je činilo kontrolnu skupinu. SSKV je primijenjena na početku i na kraju treninga na obje skupine studenata. Rezultati upućuju na dobre psihometrijske karakteristike skale, pri čemu je utvrđena dvofaktorska struktura (podskala pozitivnih i podskala negativnih stavova). Nije utvrđena statistički značajna promjena u stavovima studenata prema učenju komunikacijskih vještina ni u eksperimentalnoj ni u kontrolnoj skupini. Međutim, prosječne vrijednosti upućuju na tendenciju smanjivanja negativnih i povećavanja pozitivnih stavova nakon provedenog treninga. Rezultati upućuju na to da trajanje treninga (10 radionica) nije dovoljno za promjenu stavova.
\end{abstract}

Ključne riječi: validacija, komunikacijske i socijalne vještine, trening 
